Article

\title{
Hydrochemical Characteristics and Temporal Variations of Geothermal Water Quality in Tangtou, Shandong, China
}

\author{
Zongjun Gao ${ }^{1}$, Jiutan Liu ${ }^{1}$, Fuquan $\mathrm{Li}^{2}{ }^{2}$, Min Wang ${ }^{1}$, Jianguo Feng ${ }^{1, *}$ and Guangwei Wu ${ }^{3, *}$ \\ 1 College of Earth Science and Engineering, Shandong University of Science and Technology, Qingdao 266590, \\ Shandong, China \\ 2 The Seventh Institute of Geology and Mineral Exploration of Shandong Province, Linyi 276006, \\ Shandong, China \\ 3 Shandong Geological Environmental Monitoring Station, Jinan 250014, Shandong, China \\ * Correspondence: skd993875@sdust.edu.cn (J.F.); wuguangwei@shandong.cn (G.W.)
}

Received: 16 July 2019; Accepted: 8 August 2019; Published: 8 August 2019

\begin{abstract}
Geothermal water resources are a kind of clean energy, which is a renewable resource to a certain extent and has a high value of development and utilization. To understand the hydrochemical characteristics, origins, and temporal variations of geothermal water quality in Tangtou, 13 geothermal water samples from 2007 to 2019 and geothermal geological conditions were collected. $\mathrm{Cl}^{-}$and $\mathrm{Na}^{+}$are the major ions, which make the geothermal water belong $\mathrm{Cl}-\mathrm{Na}$ type. The total dissolved solids values of geothermal waters were 1560-2512 mg/L and pH were in the range of 6.7-8.8. The development of faulted structures provides conditions for the formation of geothermal water. In addition, geothermal water is recharged by shallow underground cold water. Water-rock interaction, as well as mixing processes, in the process of long runoff path and the slower deep-water cycle is the main factor controlling the chemical composition of geothermal water. Calculated saturation index values indicated that the geothermal water was saturated with respect to silicate and carbonate minerals. Cation and silica chemical geothermometers indicated that reservoir temperatures ranged from 94.63 to $196.10^{\circ} \mathrm{C}$ and from 69.13 to $123.75^{\circ} \mathrm{C}$, respectively. Based on the grey relational analysis, the main physicochemical components of geothermal water are obviously correlated with the geothermal water exploitation and precipitation. Overall, affected by exploitation and precipitation, main physicochemical components (such as the total dissolved solids, total hardness, temperature, $\mathrm{Na}^{+}, \mathrm{Ca}^{2+}, \mathrm{Cl}^{-}, \mathrm{K}^{+}$, and $\mathrm{Mg}^{2+}$ ) showed a certain stage.
\end{abstract}

Keywords: geothermal water; hydrochemical characteristics; temporal variations; grey relational analysis; Tangtou

\section{Introduction}

The excessive use of traditional fossil fuels will lead to a series of environmental problems. Therefore, geothermal resources, as a clean and renewable resource, have aroused extensive exploration all over the world [1]. China is a country with abundant geothermal resources, which have a good prospect for development and utilization [2,3]. Geothermal water resources are the most widely recognized and utilized geothermal resources in the world. Geothermal water can be used not only for power generation but also for heating, bathing, recuperation, health care, and so on. Therefore, the development of geothermal water resources has important social and economic value.

In the development of geothermal water, understanding the hydrochemical characteristics, influencing factors, hydrogeochemical processes, and geothermal reservoir temperatures of geothermal water are quite important. At present, many scholars have conducted a lot of research on the water 
chemistry of geothermal water and geothermal reservoirs. Yalcin [4] studied the hydrothermal chemistry of the Biga Peninsula in northwestern Turkey, distinguished the hydrochemical types and isotope composition and determined the main geochemical processes. Tan et al. [5] analyzed the geothermal mechanism of Xining Basin (China) and its adjacent areas using hydrochemical and isotopic data, and determined the geothermal source. Wang et al. [6] determined the hydrochemistry and isotopic ( $\mathrm{H}, \mathrm{O}, \mathrm{C}$, and $\mathrm{S}$ ) geochemistry characteristics of geothermal water in Nyemo-Nagqu (Tibet, China). Using geochemical, isotope, and geothermal measurement techniques, Chenaker et al. [7] defined the chemical composition, genesis, geochemical process, and thermal reservoir temperature advance of geothermal water in northeastern Algeria.

Tangtou is located in the middle of Sucun depression of Yihe graben in the Yishu fault zone of Eastern China. It has a long history of exploitation and utilization of geothermal water and is a famous sanatorium. Before the 1960s, the utilization of geothermal water was relatively low and was discharged in the form of hot springs. With the increase of geothermal wells and the exploitation of geothermal water, hot springs disappear, and the physical and chemical characteristics of geothermal water have changed significantly. However, studies on the characteristics of the geochemical composition of geothermal water over time are relatively limited. Therefore, based on the hydrochemical data of geothermal water from 2007 to 2019, the hydrochemical characteristics, origin, geochemical process and the temporal variation characteristics of main ions of geothermal water are analyzed, and the correlation between the precipitation, exploitation of geothermal water and main chemical components are identified by using grey correlation analysis. These results can provide useful information for the rational development of Tangtou geothermal water resources.

\section{Study Area}

Tangtou geothermal well (Figure 1) is located in Tangtou town, Hedong district, Linyi City, at the foot of the Tang Mountain, and the east bank of the Tang River. Geographical coordinates: east longitude $118^{\circ} 30^{\prime} 27^{\prime \prime}-118^{\circ} 30^{\prime} 56^{\prime \prime}$, north latitude $35^{\circ} 16^{\prime} 02^{\prime \prime}-35^{\circ} 16^{\prime} 28^{\prime \prime}$. The nearby terrain is generally a small dustpan-shaped basin with a high surrounding area, low in the middle, and the elevation of the ground is about $80 \mathrm{~m}$. The highest point of Tangshan is about $120 \mathrm{~m}$ above sea level. Geomorphology can be divided into (1) structural erosional terrain, distributed east of Tangshan and Tangshan, (2) denudation accumulation topography, mainly distributed in the middle of dustpan basin, with a thickness of 5-6 m, (3) alluvial topography, distributed on both banks of Tang River, with a width of 7-8 $\mathrm{m}$ and a thickness of 1-3 m. The region belongs to the warm temperate semi-humid monsoon climate zone with abundant sunshine, abundant rainfall, suitable climate, and distinct seasons. The annual average temperature is $13.4{ }^{\circ} \mathrm{C}$, and the annual average precipitation is $819.51 \mathrm{~mm}$ (1984-2018). The maximum annual precipitation is $1149 \mathrm{~mm}$ (2003) and the minimum annual precipitation is $497.6 \mathrm{~mm}$ (1988). Rainfall mostly concentrates in June-September, accounting for $71 \%$ of the annual precipitation, and the annual average evaporation is $1250 \mathrm{~mm}$ (measured on the free water surface). The rivers in the area are developed, mainly including the Yi River and the Tang River. The Yi River originates from the Lushan Mountains, with a total drainage area of $10,790 \mathrm{~km}^{2}$. It runs from north to south across Linyi City and has an average annual runoff of $16,900 \mathrm{~m}^{3} / \mathrm{s}$. Tang River is a tributary of the Shu River, running north and south across the west side of the study area, without floodplain, and the riverbed is bedrock. The Tang River bed is generally 100-150 m wide, with a water depth of $0.5-2 \mathrm{~m}$, and the geothermal well is $258 \mathrm{~m}$ away from Tang River.

The exposed strata and lithology (Figure 1) are mainly andesite, andesite tuff of Bamudi Formation $\left(\mathrm{K}_{1} \mathrm{~b}\right)$ of Cretaceous Qingshan Group, sandstone conglomerate of Malanggou Formation $\left(\mathrm{K}_{1} \mathrm{ml}\right)$ of Dasheng Group and sandstone of Tianjialou Formation $\left(K_{1} t\right)$. Around the geothermal well, there are reddish-brown and purplish-brown andesite with dense lithology and obvious phenocryst structure. The borehole histogram of the geothermal well is shown in Figure 2. The northwest part is covered with purplish-brown glutenite and conglomerate of Dasheng Group. The famous Tangtou Hot Spring 
is exposed to the contact zone between the Cretaceous Andesite and the glutenite at the intersection of the faults.
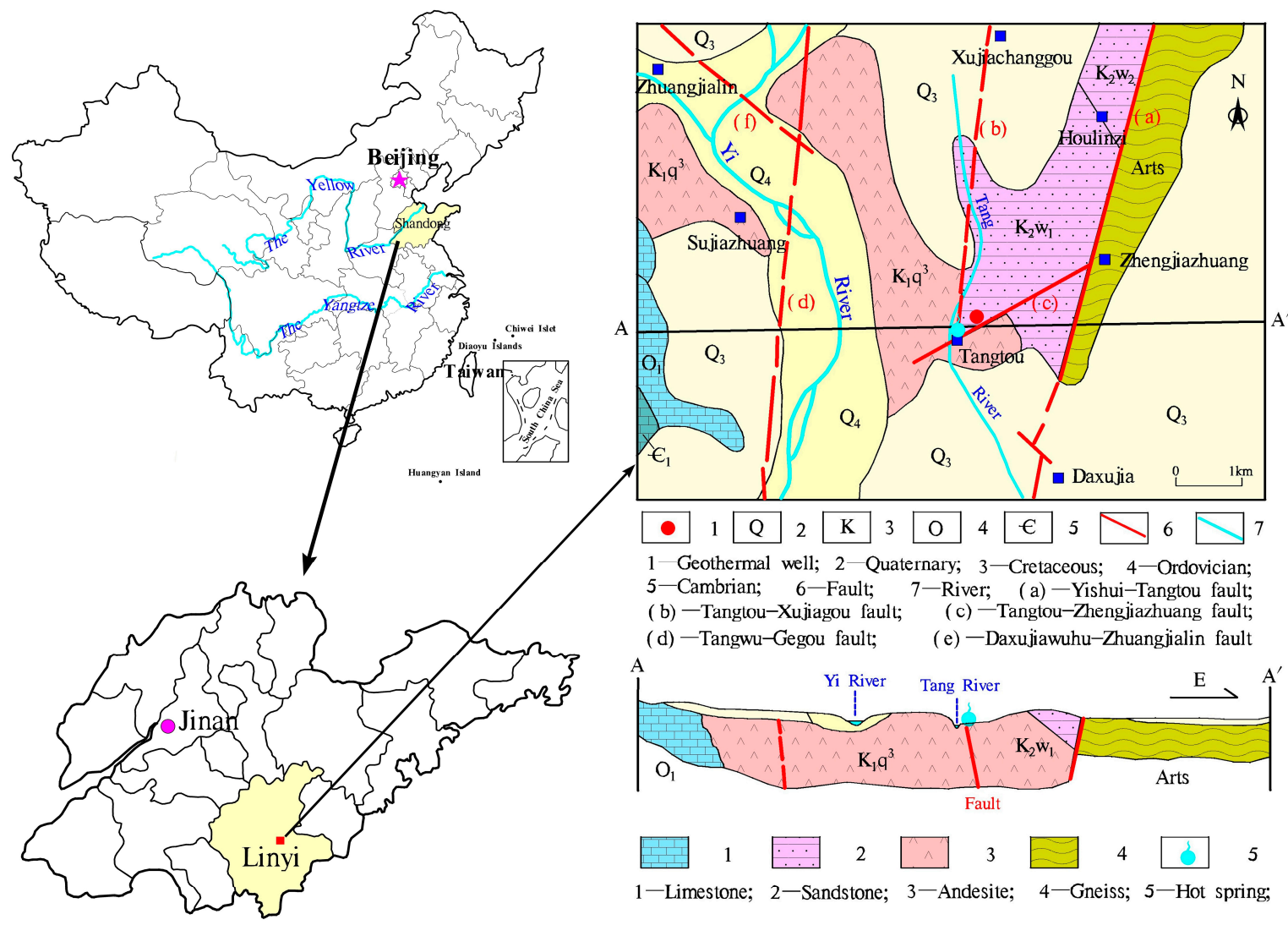

Figure 1. Location and regional geological sketch of the study area.

The groundwater in the area is divided into Quaternary loose rock pore water and bedrock pore-fracture water. The Quaternary loose rock pore water aquifer is mainly sandy clay and medium-fine sand with gravel. The source of recharge mainly receives meteoric water infiltration and river recharge and the direction of runoff is consistent with the direction of topographic inclination. The bedrock fissure water-bearing rock group is the Cretaceous andesite and glutenite, and weathering fissures and tectonic fissures are relatively developed. The groundwater dynamics are significantly affected by precipitation and river water. In the natural state, the bedrock fissure water is discharged to the river water. Under the mining conditions, river water seepage is replenished, and artificial mining is the main way of excretion.

The Tangtou geothermal is mainly distributed along the Tangtou-Zhengjiazhuang fault width of about $80 \mathrm{~m}$. The thermal reservoir is the Cretaceous Anshan basalt fracture zone. The thermal reservoir roof is buried about $80 \mathrm{~m}$ deep, and the general single well water inflow is $20 \mathrm{~m}^{3} / \mathrm{h}$. Atmospheric precipitation is its principal source of recharge. The Cretaceous fault zone is widely distributed and the secondary fault structure is developed. Groundwater flows from the west, north, and east to the south. After deep circulation heating, the groundwater continues to move southward along the bottom of the rock mass or through the near-north-south fracture zone, and is enriched when blocked by rock mass or fault. Covering the thick Cretaceous caprock, the deep groundwater is in a relatively closed environment, and the underground hot water is discharged along the fault zone to the surface to form a shallow geothermal anomaly zone or overflow the surface. In the natural state, it is recharged along structural fissures in the north-east and runoff to the south-west, and springs emerge in low-lying terrain. At present, artificial mining is the main way of excretion of geothermal energy. 


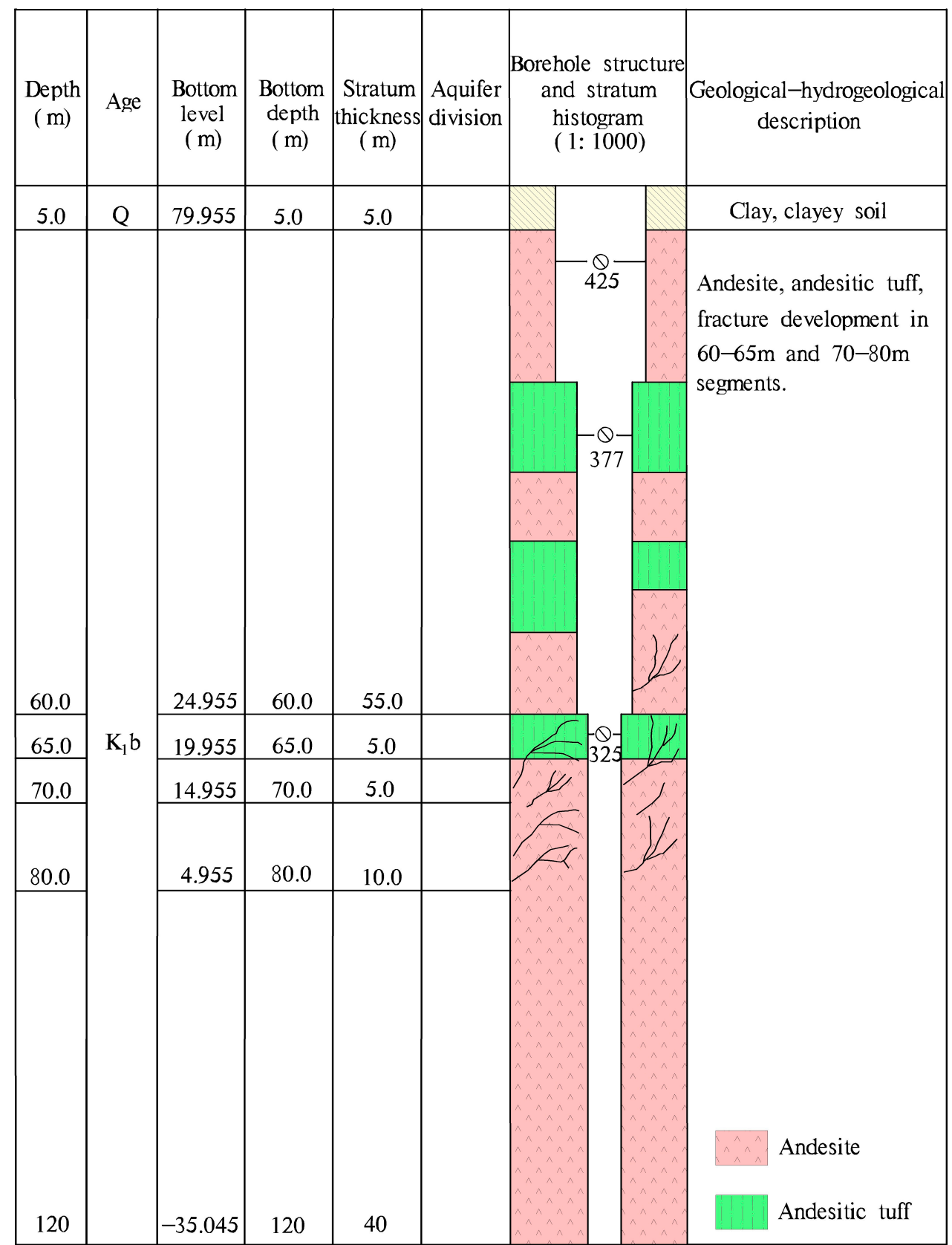

Figure 2. Borehole histogram of geothermal well.

\section{Materials and Methods}

\subsection{Sampling and Analysis}

A total of 13 geothermal water samples were collected from Tangtou geothermal well (Figure 1) during 2007 to 2019. Among them, the sampling time of 2007, 2009-2011 and 2015-2018 was June of each year. The sampling time of 2013 was November, 2014 was March, and 2019 was January. The samples were taken from clean plastic bottles washed 2-3 times with geothermal water. When sampling, water samples are filled with sampling bottles and sealed to prevent leakage. Geothermal water temperature $\left(\mathrm{T}^{\circ} \mathrm{C}\right)$ was measured at the sampling site. After sampling, the samples were sent to the laboratory in time for water quality testing.

The $\mathrm{pH}$ level was determined by the acidity meter (PHS-3C). Total hardness (TH) and $\mathrm{HCO}_{3}{ }^{-}$ were measured by using titration. TDS was measured by the weighing method (electronic balance, 
PRACTUM124-1CN). Major ions $\left(\mathrm{Ca}^{2+}, \mathrm{Mg}^{2+}, \mathrm{Na}^{+}, \mathrm{K}^{+}, \mathrm{SO}_{4}{ }^{2-}, \mathrm{Cl}^{-}\right.$, and $\left.\mathrm{NO}_{3}{ }^{-}\right)$were analyzed by using ion chromatography (IC-600S), and $\mathrm{H}_{2} \mathrm{SiO}_{3}$ was measured by silicon-molybdenum blue colorimetry. Ion balance errors of the water samples were $<5 \%$. In addition, the geothermal water exploitation and precipitation from 2007 to 2019 of the study areas were also collected from the seventh Institute of Geology and Mineral Exploration of Shandong Province.

\subsection{Methods}

\subsubsection{Principal Component Analysis}

Principal component analysis (PCA) method has been widely used to analyze the origin of Hydrochemistry and its influencing factors [8-10]. By detecting the similarity between hydrochemistry, the potential processes affecting the formation of chemical components in groundwater can be inferred. In this study, PCA was used to determine the possible processes affecting the chemical composition of geothermal water of Tangtou.

\subsubsection{Grey Relational Analysis}

Grey relational analysis (GRA) was an effective pattern recognition method in grey system theory, which was widely used. The basic idea of GRA is to quantify the degree of correlation between the factors according to the similarity of the geometric shape of the sequence curve [11,12]. The closer the shape of the curve is, the greater the degree of correlation, and vice versa. The grey correlation analysis steps are as follows:

The first step is de-dimensionalization.

$$
x_{i}(k)=\frac{x_{i}^{\prime}}{x_{i}}
$$

where, $x_{i}^{\prime}$ is actual measured value of hydrochemical factors, $x_{i}$ is the average of each factor.

Let the standardized reference sequence is $\left\{x_{0}(k)\right\}=\left\{x_{01}, x_{02}, \cdots, x_{0 n}\right\}$, then the correlation degree comparison sequence as follows:

$$
\left\{x_{1}(k), x_{2}(k), \cdots, x_{m}(k)\right\}=\left[\begin{array}{cccc}
x_{11} & x_{12} & \cdots & x_{1 n} \\
x_{21} & x_{22} & \cdots & x_{2 n} \\
\vdots & \vdots & \cdots & \vdots \\
x_{m 1} & x_{m 2} & \cdots & x_{m n}
\end{array}\right]
$$

where, $m$ is the number of sequences and $n$ is the number of data. Then, the absolute difference between the comparison sequence and the corresponding reference sequence can be calculated using the following formula:

$$
\Delta_{i}(k)=\left|x_{0}(k)-x_{i}(k)\right|
$$

The third step is to calculate the correlation coefficient $\zeta$.

$$
\zeta_{i}(k)=\frac{\Delta(\min )+\rho \Delta(\max )}{\Delta_{i}(k)+\rho \Delta(\max )}
$$

where, $\Delta(\min )$ and $\Delta(\max )$ represent the maximum and minimum absolute differences in all sequences, respectively. $\rho$ indicates the differentiation coefficient, which can reduce the deformation effect caused by large absolute error and improve the significant difference of the correlation coefficient [12].

Finally, the correlation degree $r$ can be expressed as:

$$
r_{i 0}=\frac{1}{n} \sum_{i=1}^{n} \zeta_{i}(k)
$$


The value of $\rho$ is between 0 and 1 , usually 0.5 . However, numerous studies have indicated that $\rho=0.5$ and may even change the correlation coefficient, resulting in erroneous analysis results $[11,13,14]$. Thus, the values of differentiation coefficients need to be improved [11] as follows:

Let $X_{0}^{\prime}=\left\{x_{0}^{\prime}(k)\right\}$ and $X_{i}^{\prime}=\left\{x_{i}^{\prime}(k)\right\}$ are the new sequences of after initialization of the reference sequence $X_{0}$ and the comparison sequence $X_{i}$, respectively. Let

$$
\Delta_{i}(k)=\left|x_{i}^{\prime}-x_{0}^{\prime}\right|
$$

then

$$
\Delta=\left[\begin{array}{cccc}
\Delta_{1}(1) & \Delta_{1}(2) & \cdots & \Delta_{1}(n) \\
\Delta_{2}(1) & \Delta_{2}(2) & \cdots & \Delta_{2}(n) \\
\vdots & \vdots & \cdots & \vdots \\
\Delta_{m}(1) & \Delta_{m}(2) & \cdots & \Delta_{m}(n)
\end{array}\right]
$$

Let

$$
\begin{gathered}
\Delta_{v}(k)=\frac{1}{m} \sum_{i=1}^{m} \Delta_{i}(k) k=1,2, \cdots, n \\
\varepsilon(k)=\frac{\Delta_{v}(k)}{\Delta(\max )}
\end{gathered}
$$

Let

$$
\rho=\{\rho(1), \rho(2), \cdots, \rho(n)\}
$$

The value of $\rho(k)$ can be determined as follows:

(1) when $\frac{1}{\varepsilon(k)}>3, \rho(k)=1.5 \varepsilon(k)$;

(2) when $2 \leq \frac{1}{\varepsilon(k)} \leq 3, \rho(k)=2 \varepsilon(k)$;

(3) when $0<\frac{1}{\varepsilon(k)}<2, \rho(k)$ can be arbitrarily selected in $[0.8,1]$

(4) when $\varepsilon(k)=0$, the value of $\zeta_{i}(k)$ is independent of $\rho(k)$, and $\rho(k)$ is arbitrary between $(0,1]$.

\subsubsection{Geothermal Reservoir Temperature}

Geochemical thermometers were often used to estimate the temperature of the geothermal reservoir. The geochemical geothermal thermometers are the underground thermal reservoir temperature calculated by the chemical composition concentration of underground hot water, which is of great significance in geothermal field potential prediction, geothermal resource exploration and development and research $[15,16]$. In this study, the silica and cation geothermometers (Table 1) were used to estimate the reservoir temperature of Tangtou.

Table 1. The calculation formulas of silica and cation geothermometers.

\begin{tabular}{ccc}
\hline Geothermometers & Calculation Formulas & References \\
\hline $\mathrm{A}\left({ }^{\circ} \mathrm{C}\right): \mathrm{Na}-\mathrm{K}$ & $\mathrm{T}=[1217 /(1.483+\log (\mathrm{Na} / \mathrm{K}))]-273.15$ & {$[17]$} \\
$\mathrm{B}\left({ }^{\circ} \mathrm{C}\right): \mathrm{Na}-\mathrm{K}$ & $\mathrm{T}=[856 /(0.857+\log (\mathrm{Na} / \mathrm{K}))]-273.15$ & {$[18]$} \\
$\mathrm{C}\left({ }^{\circ} \mathrm{C}\right): \mathrm{Na}-\mathrm{K}$ & $\mathrm{T}=\{1390 /[\log (\mathrm{Na} / \mathrm{K})+1.75]\}-273.15$ & {$[19]$} \\
$\mathrm{D}\left({ }^{\circ} \mathrm{C}\right): \mathrm{K}-\mathrm{Mg}$ & $\mathrm{T}=\left\{4410 /\left[14-\log \left(\mathrm{K}^{2} / \mathrm{Mg}\right)\right]\right\}-273.15$ & {$[19]$} \\
$\mathrm{E}\left({ }^{\circ} \mathrm{C}\right):$ Chalcedony & $\mathrm{T}=\left[1032 /\left(4.69-\log \mathrm{SiO}_{2}\right)\right]-273.15$ & {$[17]$} \\
$\mathrm{F}\left({ }^{\circ} \mathrm{C}\right):$ Quartz & $\mathrm{T}=\left[1309 /\left(5.19-\log \mathrm{SiO}_{2}\right)\right]-273.15$ & {$[17]$} \\
$\mathrm{J}\left({ }^{\circ} \mathrm{C}\right):$ Silica & $\mathrm{T}=\left[1000 /\left(4.55-\log \mathrm{SiO}_{2}\right)\right]-273.15$ & {$[20]$} \\
\hline
\end{tabular}




\section{Results and Discussion}

\subsection{Geothermal Water Chemistry}

Physico-chemical data of Tangtou geothermal water from 2007 to 2019 were shown in Table 2. The Temperatures $\left({ }^{\circ} \mathrm{C}\right.$ ) of geothermal water range from $50{ }^{\circ} \mathrm{C}$ to $60{ }^{\circ} \mathrm{C}$ with a mean of $55.93{ }^{\circ} \mathrm{C}$ and the lowest temperature $\left(50^{\circ} \mathrm{C}\right)$ occurred in June 2016 . The $\mathrm{pH}$ values were in the range of 6.7-8.8, with a mean of 7.73. Therefore, geothermal waters in Tangtou are slightly alkaline. Contents of major ions in the geothermal water are $\mathrm{Na}^{+}>\mathrm{Ca}^{2+}>\mathrm{K}^{+}>\mathrm{Mg}^{2+}$ and $\mathrm{Cl}^{-}>\mathrm{SO}_{4}{ }^{2-}>\mathrm{HCO}_{3}{ }^{-}>\mathrm{NO}_{3}{ }^{-}$, according to Schoeller diagram (Figure 3).

Table 2. Physicochemical parameters and saturation index statistics of geothermal water.

\begin{tabular}{ccccc}
\hline & Max & Min & Mean & SD \\
\hline $\mathrm{Cl}^{-}(\mathrm{mg} / \mathrm{L})$ & 1123.00 & 557.28 & 814.51 & 136.52 \\
$\mathrm{SO}_{4}{ }^{2-}(\mathrm{mg} / \mathrm{L})$ & 278.20 & 158.40 & 219.94 & 39.18 \\
$\mathrm{HCO}_{3}{ }^{-}(\mathrm{mg} / \mathrm{L})$ & 277.03 & 123.60 & 182.42 & 47.53 \\
$\mathrm{NO}_{3}{ }^{-}(\mathrm{mg} / \mathrm{L})$ & 63.29 & 4.49 & 29.63 & 17.60 \\
$\mathrm{~K}^{+}(\mathrm{mg} / \mathrm{L})$ & 30.01 & 20.50 & 25.31 & 2.81 \\
$\mathrm{Na}^{+}(\mathrm{mg} / \mathrm{L})$ & 566.20 & 356.73 & 465.05 & 55.04 \\
$\mathrm{Ca}^{2+}(\mathrm{mg} / \mathrm{L})$ & 256.00 & 147.66 & 183.80 & 30.20 \\
$\mathrm{Mg}^{2+}(\mathrm{mg} / \mathrm{L})$ & 6.09 & 0.89 & 3.38 & 1.33 \\
$\mathrm{TH}(\mathrm{mg} / \mathrm{L})$ & 658.96 & 381.88 & 472.89 & 75.94 \\
$\mathrm{H}_{2} \mathrm{SiO}(\mathrm{mg} / \mathrm{L})$ & 104.0 & 56.16 & 85.11 & 14.60 \\
$\mathrm{pH}$ & 8.8 & 6.7 & 7.73 & 0.54 \\
$\mathrm{TDS}(\mathrm{mg} / \mathrm{L})$ & 2512 & 1560 & 1963.49 & 247.76 \\
$\mathrm{~T}\left({ }^{\circ} \mathrm{C}\right)$ & 60.00 & 50.00 & 55.93 & 3.89 \\
$\mathrm{SI}($ Anhydrite $)$ & -0.99 & -1.28 & -1.13 & 0.09 \\
$\mathrm{SI}$ (Aragonite) & 1.81 & -0.09 & 0.89 & 0.51 \\
$\mathrm{SI}($ Calcite $)$ & 1.93 & 0.03 & 1.01 & 0.51 \\
$\mathrm{SI}($ Chalcedony) & 0.39 & 0.07 & 0.24 & 0.11 \\
\hline $\mathrm{SI}$ (Dolomite) & 2.73 & -1.05 & 0.78 & 1.05 \\
$\mathrm{SI}$ (Gypsum) & -0.95 & -1.28 & -1.14 & 0.09 \\
$\mathrm{SI}$ (Halite) & -5.00 & -5.35 & -5.12 & 0.11 \\
$\mathrm{SI}$ (Quartz) & 0.75 & 0.41 & 0.59 & 0.10 \\
\hline
\end{tabular}

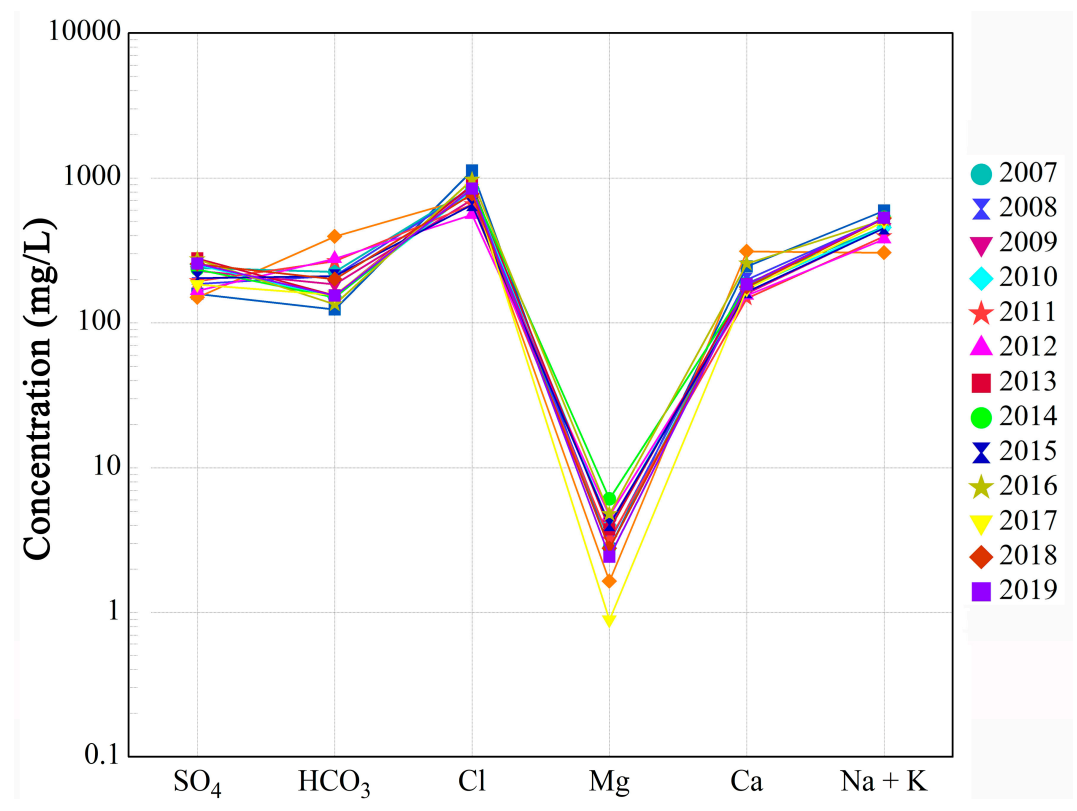

Figure 3. Schoeller diagram of geothermal water samples. 
$\mathrm{Na}^{+}$and $\mathrm{Cl}^{-}$concentrations range from 356.73 to $566.20 \mathrm{mg} / \mathrm{L}$ and 557.28 to $1123.00 \mathrm{mg} / \mathrm{L}$, with a mean equal to 465.05 and $814.51 \mathrm{mg} / \mathrm{L}$, respectively. $\mathrm{Mg}^{2+}$ contents in geothermal water are relatively low, and the maximum value is not more than $10 \mathrm{mg} / \mathrm{L}$, with an average value of $3.38 \mathrm{mg} / \mathrm{L}$. The measured TDS values of geothermal waters were $1560-2512 \mathrm{mg} / \mathrm{L}$, and TH values were 381.88-658.96 mg/L (Table 2).

The water types were determined by using Piper diagram [21], which was a simple and practical method to classify hydrochemical facies. As shown in Figure 4, $\mathrm{Na}^{+}$and $\mathrm{Cl}^{-}$are the dominant ions. All water samples are plotted on the zone D (sodium type) of the lower left triangle. With respect to anions, all samples belong to chloride type (zone G). Therefore, the geothermal water type of Tangtou from 2007 to 2019 was Cl-Na.

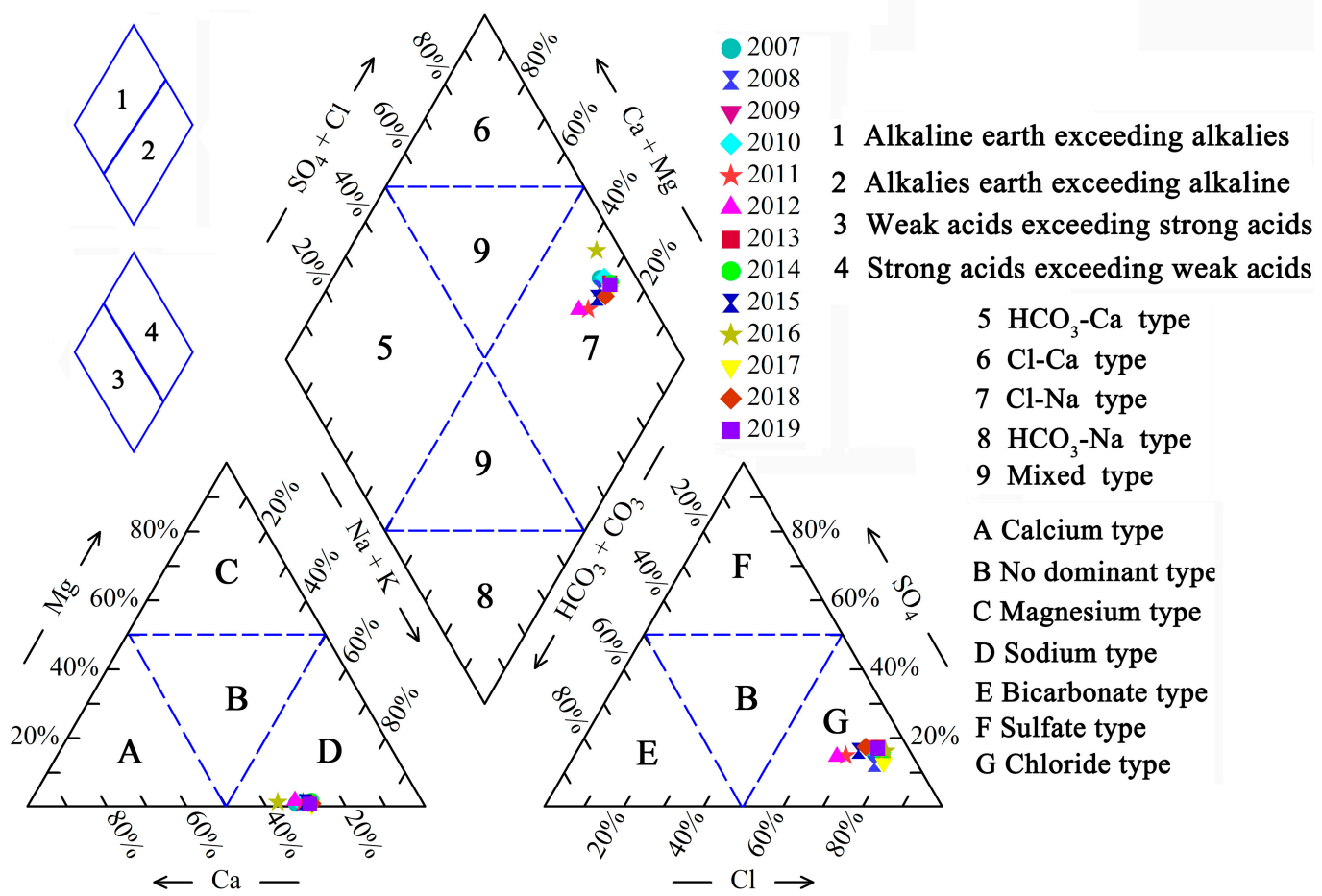

Figure 4. Piper diagram of geothermal water.

Generally speaking, $\mathrm{Cl}^{-}$is considered conservative due to the general lack of chlorine-bearing minerals (excluding halite) in aquifers [2,22]. Therefore, $\mathrm{Cl}^{-}$is usually considered as an important parameter in the analysis of geothermal water chemical characteristics [3,23]. The $\mathrm{Cl}^{-}$concentrations of geothermal water versus some major chemical components were illustrated in Figure $5 . \mathrm{Cl}^{-}$of Tangtou geothermal water indicates a positive correlation with TDS $\left(R^{2}=0.56, \mathrm{p}<0.01\right)$, suggesting that the contribution of $\mathrm{Cl}^{-}$to TDS.

A positive correlation was found between $\mathrm{Cl}^{-}$and $\mathrm{Na}^{+}\left(R^{2}=0.64, \mathrm{p}<0.01\right), \mathrm{Cl}^{-}-\mathrm{K}^{+}\left(R^{2}=0.68\right.$, $\mathrm{p}<0.01), \mathrm{Cl}^{-}-\mathrm{Ca}^{2+}\left(R^{2}=0.63, \mathrm{p}<0.01\right)$, and $\mathrm{Cl}^{-}-\mathrm{SiO}_{2}\left(R^{2}=0.41, \mathrm{p}<0.05\right)$ which may indicate the dissolution of halite and the weathering of silicate minerals. However, $\mathrm{Cl}^{-}$and $\mathrm{HCO}_{3}{ }^{-}$had a significant negative correlation $\left(R^{2}=0.63, \mathrm{p}<0.01\right)$, which indicated that $\mathrm{HCO}_{3}{ }^{-}$decreased with the increasing of $\mathrm{Cl}^{-}$. During the long flow process of geothermal water, leaching, evaporation, and concentration occur along the way, which increases the $\mathrm{Cl}^{-}$content and decreases the $\mathrm{HCO}_{3}{ }^{-}$content. Evaporation reduces water content, but salt remains in the remaining water. With the continuation of time, the geothermal water solution is gradually concentrated and the salinity continuously increased. Salts with low solubility are saturated and precipitated from water, while the ions of the soluble salts $\left(\mathrm{Na}^{+}\right.$and $\left.\mathrm{Cl}^{-}\right)$ gradually become the main components of the geothermal water. The low $\mathrm{HCO}_{3}{ }^{-} / \mathrm{Cl}^{-}$and $\mathrm{SO}_{4}{ }^{2-} / \mathrm{Cl}^{-}$ ratios in geothermal water indicate that underground hot water undergoes a longer runoff path and a 
slower deep-water cycle [2]. In addition, the difference in ratios also shows that the difference of the extent of reaction, sampling time, cold groundwater recharge, and human factors.
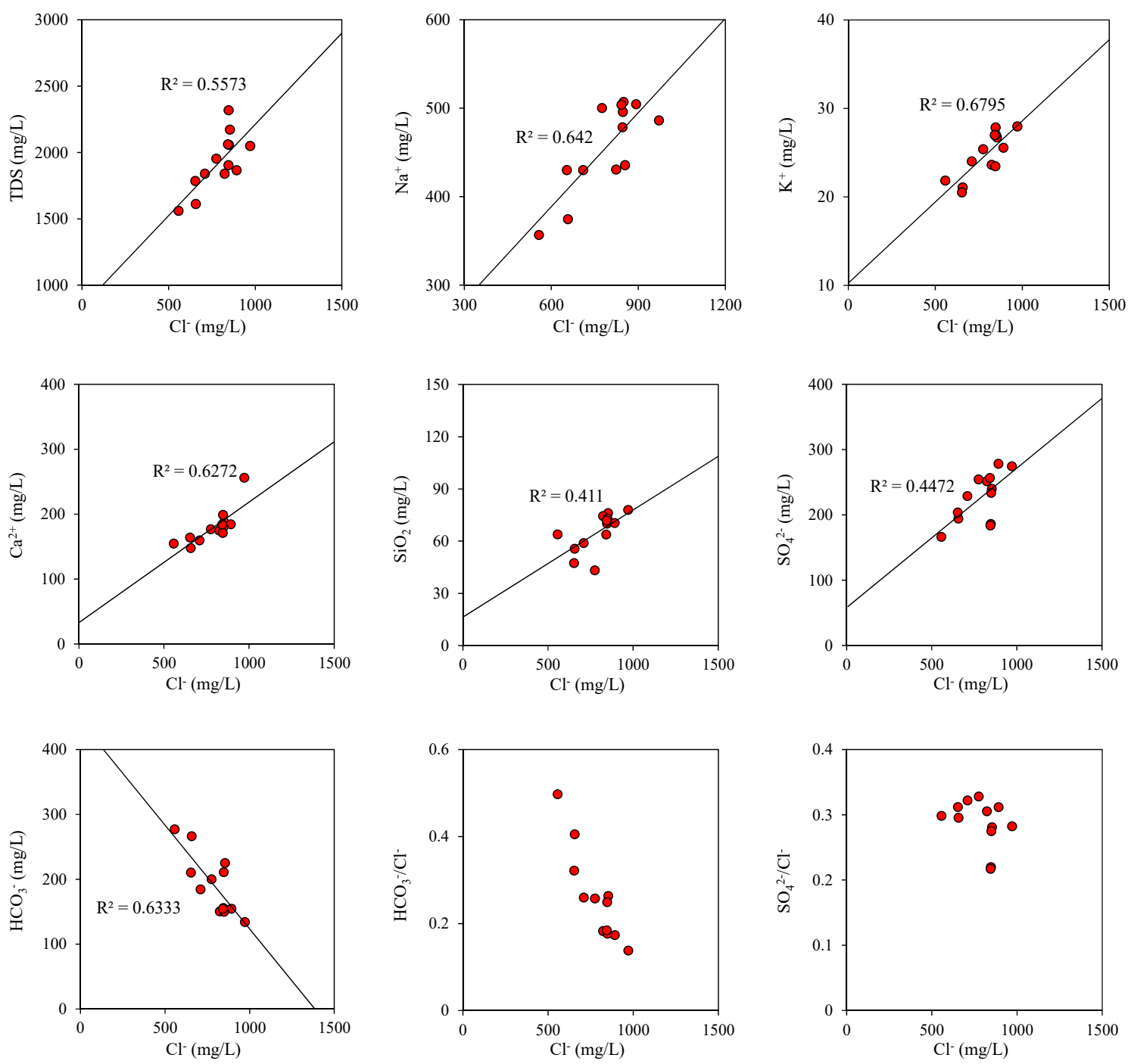

Figure 5. Relations between $\mathrm{Cl}^{-}$and major chemical components in geothermal water.

In order to determine the possible processes affecting the chemical composition of geothermal water, the PCA method was applied. In this study, 13 geothermal water samples from 2007 to 2019 were used for PCA by using SPSS software. Results present that three principal components (eigenvalue $>1$ ) were obtained with a Kaiser-Meyer-Olkin value of 0.644. As shown in Table 3 and Figure 6, the three principal components explained about $77 \%$ of the total variance. 
Table 3. Rotated component matrix.

\begin{tabular}{cccc}
\hline \multirow{2}{*}{ Variables } & \multicolumn{3}{c}{ Principal Components } \\
\cline { 2 - 4 } & PC1 & PC2 & PC3 \\
\hline $\mathrm{Cl}^{-}$ & 0.981 & 0.008 & -0.042 \\
$\mathrm{Ca}^{2+}$ & 0.888 & -0.146 & 0.105 \\
$\mathrm{Na}^{+}$ & 0.851 & 0.288 & -0.070 \\
$\mathrm{HCO}_{3}{ }^{-}$ & -0.822 & -0.203 & -0.088 \\
$\mathrm{~K}^{+}$ & 0.760 & 0.486 & -0.031 \\
$\mathrm{H}_{2} \mathrm{SiO}_{3}$ & 0.697 & -0.328 & 0.130 \\
$\mathrm{NO}_{3}{ }^{-}$ & -0.105 & 0.864 & -0.239 \\
$\mathrm{pH}^{2+}$ & -0.179 & -0.777 & -0.218 \\
$\mathrm{Mg}^{2+}$ & -0.117 & -0.272 & 0.819 \\
$\mathrm{SO}_{4}{ }^{2-}$ & 0.172 & 0.231 & 0.766 \\
Eigenvalue & 4.300 & 1.968 & 1.405 \\
Variance (\%) & 42.996 & 19.681 & 14.054 \\
Cumulative of variance (\%) & 42.996 & 62.677 & 76.731 \\
\hline
\end{tabular}

Principal component 1, explaining for $43 \%$ of the total variance of geothermal water data, had positive correlations with $\mathrm{Cl}^{-}, \mathrm{Ca}^{2+}, \mathrm{Na}^{+}, \mathrm{HCO}_{3}{ }^{-}, \mathrm{K}^{+}$, and $\mathrm{H}_{2} \mathrm{SiO}_{3}$. The lithology around the geothermal well is mainly andesite and sandy conglomerate, in which the main mineral components of andesite are feldspar and amphibole, and the sandy conglomerate is calcareous cementation. Therefore, principal component 1 likely represented the long-term solution, concentration, and water-rock interaction between geothermal water and surrounding rock. Principal component 2 accounted for $20 \%$ of the total variance and has a loading for $\mathrm{NO}_{3}{ }^{-} \cdot \mathrm{NO}_{3}{ }^{-}$is a typical factor affected by human activities, such as agricultural fertilizer, human and animal excreta, and industrial sewage discharge and so on, which may be the source of $\mathrm{NO}_{3}{ }^{-}$[24]. Therefore, principal component 2 may represent the influence of human activities. On the other hand, it also indicates that geothermal water is recharged by surface water or cold groundwater. In addition, in previous studies of thermal fluids in the Yishu fault zone, hydrogen and oxygen isotopes indicate that the source of geothermal water is atmospheric precipitation [25]. Principal component 3 accounts for $14 \%$ of the total variance with high loadings for $\mathrm{Mg}^{2+}$ and $\mathrm{SO}_{4}{ }^{2-}$. Principal component 3 may indicate the dissolution of magnesium sulfate minerals, but the low content of $\mathrm{Mg}^{2+}$ in geothermal water indicates that it has little influence.
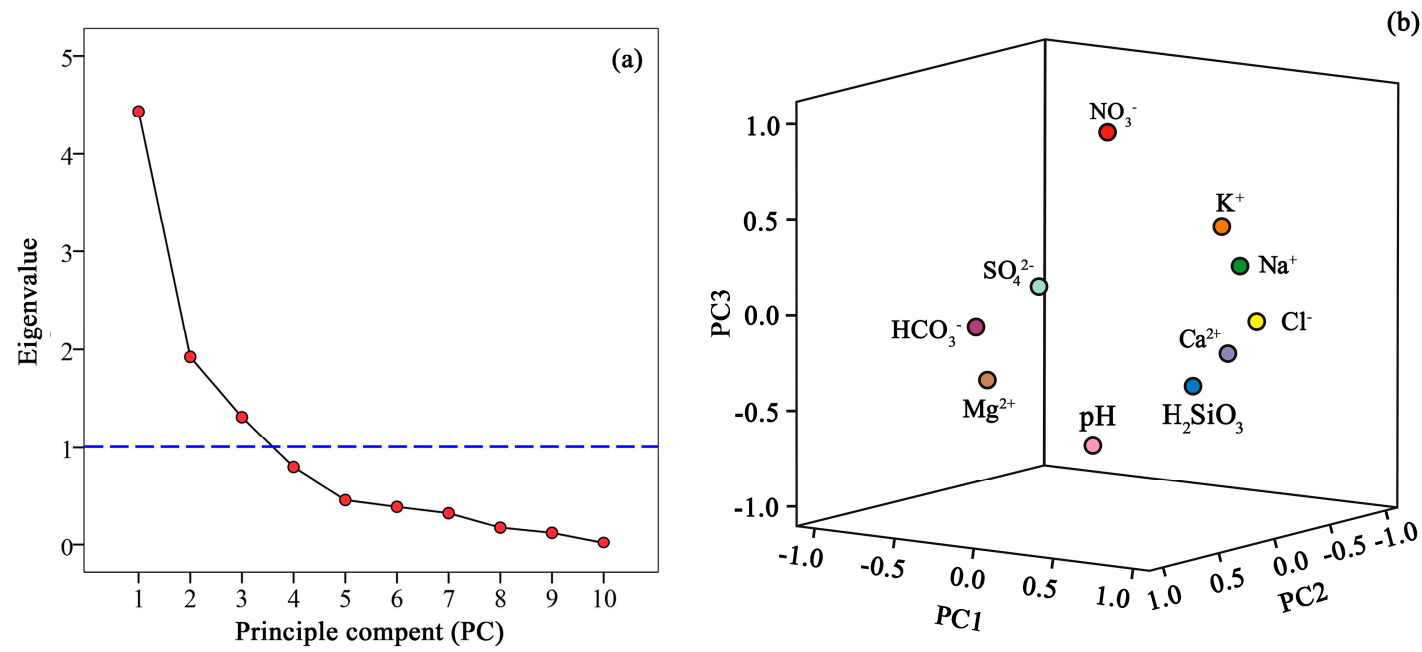

Figure 6. (a) Scree plot; (b) Principle component loadings for PC1, PC2 and PC3. 


\subsection{Saturation Index}

Saturation index (SI) value can indicate the dissolution equilibrium state of relevant minerals. In this study, SI values for relevant minerals were calculated by the geochemical program PHREEQC. The SI values of relevant minerals presented in Table 1 and saturation state results reported in Figure 7. The SI values of quartz and chalcedony have a range from $0.41-0.75$ and $0.07-0.39$ with a mean of 0.59 and 0.24 , respectively. For dolomite, calcite, and aragonite, the SI values of most samples were larger than 0 , while with respect to anhydrite, halite, and gypsum, the SI values of most thermal water samples were less than 0 . Overall, results indicated that the geothermal water samples are saturated with respect to quartz, chalcedony, dolomite, calcite, and aragonite while unsaturated with respect to anhydrite, halite, and gypsum at the wellhead temperatures.

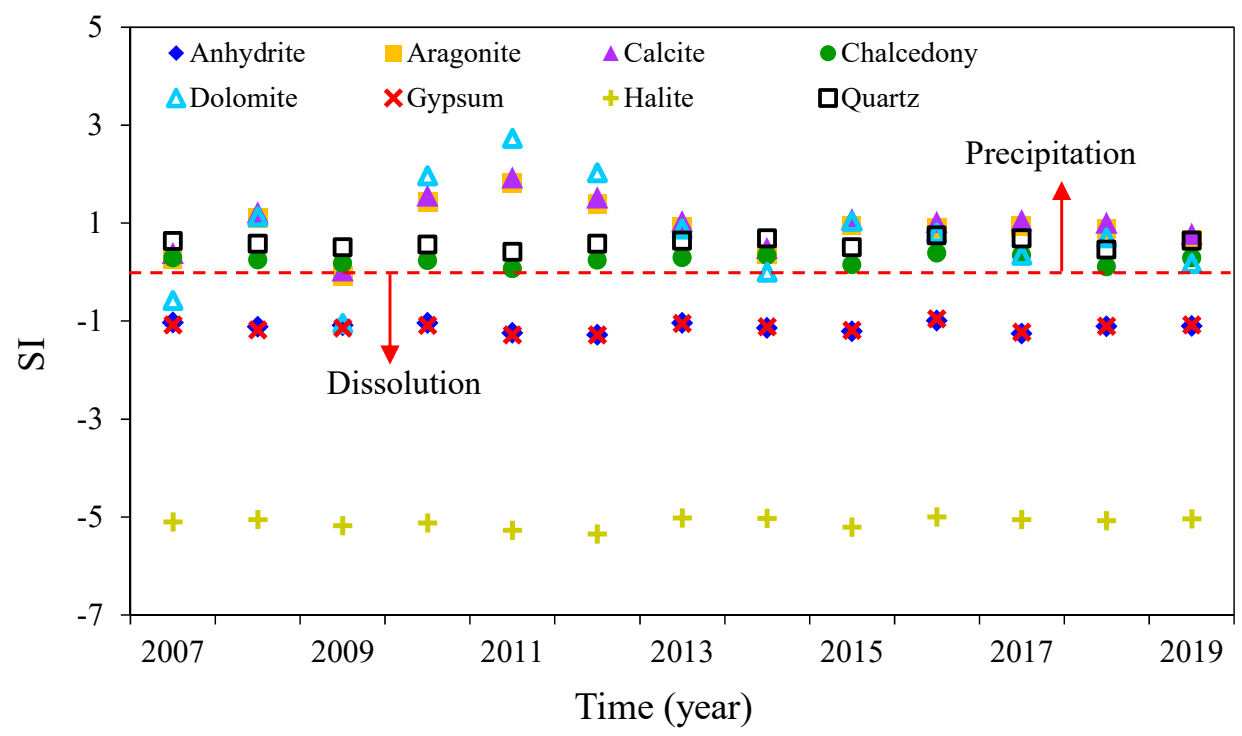

Figure 7. SI values for relevant minerals from Tangtou geothermal waters.

\subsection{Geothermal Reservoir Temperature}

To estimate the Tangtou reservoir temperature for geothermal water samples from 2007 to 2019, cation and silica chemical geothermometers were applied and the calculated results were shown in Table 4 and Figure 8 . The calculated temperatures showed an order of $\mathrm{C}\left({ }^{\circ} \mathrm{C}\right)>\mathrm{A}\left({ }^{\circ} \mathrm{C}\right)>\mathrm{B}\left({ }^{\circ} \mathrm{C}\right)>\mathrm{F}\left({ }^{\circ} \mathrm{C}\right)$ $>\mathrm{D}\left({ }^{\circ} \mathrm{C}\right)>\mathrm{J}\left({ }^{\circ} \mathrm{C}\right)>\mathrm{E}\left({ }^{\circ} \mathrm{C}\right)$. The largest estimated reservoir temperatures were determined by cationic geothermometers, while the minimum temperatures were given by chalcedony geothermometers. Water temperatures estimated by the Na-K geothermometers (A to C) ranged from 119.74 to 196.10 ${ }^{\circ} \mathrm{C}$, while temperatures estimated by $\mathrm{K}-\mathrm{Mg}$ (D) geothermometers varied from 94.63 to $120.29{ }^{\circ} \mathrm{C}$ (Table 4). The silica geothermometers from $\mathrm{E}\left({ }^{\circ} \mathrm{C}\right)$ to $\mathrm{F}\left({ }^{\circ} \mathrm{C}\right)$ indicated a result of ranging from 69.13 to $123.75^{\circ} \mathrm{C}$. The precipitation or mixing process of silica may result in lower estimated temperature of silica geothermometers $[22,26]$. Thus, the temperatures calculated by quartz geothermometers $\left(\mathrm{F}\left({ }^{\circ} \mathrm{C}\right)\right)$ was higher and a lower temperature was obtained by chalcedony $\left(\mathrm{E}\left({ }^{\circ} \mathrm{C}\right)\right)$ geothermometers. As shown in Table 4 and Figure 8, the estimated water temperature is obviously higher than that at the wellhead of geothermal wells and the estimated temperature have a certain floating over time, which may be due to the continuous loss of heat during the upward migration of underground hot water, the change of the concentration of its chemical components due to the water-rock interaction and the mixing with cold water [22,26]. In addition, the recharge of surface water and underground cold water is also an important factor leading to the decrease of geothermal water temperature.

A Na-K-Mg ${ }^{1 / 2}$ ternary diagram proposed by Giggenbach [19] was used to determine equilibration processes and estimate the reservoir temperature [2,15]. As shown in Figure 9, thermal water samples from 2007 to 2019 located on the both sides of the boundary between immature waters and partially 
equilibrated or mixed waters, and most samples plotted on immature waters zone, which may mean that the geothermal water of the study area was influenced by mixing with cold groundwater and dilution [22,27].

Table 4. Geothermometry results for the geothermal waters from Tangtou.

\begin{tabular}{ccccccccc}
\hline Time & $\begin{array}{c}\text { Wellhead } \\
\text { Temperature }\left({ }^{\circ} \mathbf{C}\right)\end{array}$ & $\mathbf{A}\left({ }^{\circ} \mathbf{C}\right)$ & $\mathbf{B}\left({ }^{\circ} \mathbf{C}\right)$ & $\mathbf{C}\left({ }^{\circ} \mathbf{C}\right)$ & $\mathbf{D}\left({ }^{\circ} \mathbf{C}\right)$ & $\mathbf{E}\left({ }^{\circ} \mathbf{C}\right)$ & $\mathbf{F}\left({ }^{\circ} \mathbf{C}\right)$ & $\mathbf{J}\left({ }^{\circ} \mathbf{C}\right)$ \\
\hline 2007 & 60.0 & 178.40 & 140.55 & 196.10 & 107.30 & 94.30 & 122.49 & 101.59 \\
2008 & 60.0 & 172.03 & 132.98 & 190.07 & 106.99 & 89.64 & 118.23 & 96.59 \\
2009 & 60.0 & 171.62 & 132.49 & 189.68 & 98.96 & 80.23 & 109.56 & 86.52 \\
2010 & 60.0 & 170.38 & 131.03 & 188.51 & 98.83 & 92.96 & 121.27 & 100.15 \\
2011 & 58.0 & 172.17 & 133.14 & 190.20 & 98.74 & 77.33 & 106.87 & 83.41 \\
2012 & 55.0 & 178.24 & 140.36 & 195.96 & 94.63 & 84.58 & 113.57 & 91.17 \\
2013 & 55.0 & 164.85 & 124.53 & 183.26 & 101.86 & 89.92 & 118.48 & 96.89 \\
2014 & 53.0 & 168.33 & 128.61 & 186.56 & 96.76 & 91.87 & 120.27 & 98.97 \\
2015 & 52.0 & 160.76 & 119.74 & 179.37 & 94.88 & 69.13 & 99.25 & 74.67 \\
2016 & 50.0 & 173.78 & 135.05 & 191.73 & 100.99 & 95.67 & 123.75 & 103.06 \\
2017 & 51.4 & 162.67 & 121.97 & 181.18 & 120.29 & 91.05 & 119.52 & 98.10 \\
2018 & 52.5 & 165.00 & 124.70 & 183.40 & 105.88 & 64.71 & 95.11 & 69.96 \\
2019 & 52.0 & 168.73 & 129.08 & 186.94 & 109.55 & 84.48 & 113.48 & 91.06 \\
Max & 60 & 178.4 & 140.55 & 196.1 & 120.29 & 95.67 & 123.75 & 103.06 \\
Min & 50 & 160.76 & 119.74 & 179.37 & 94.63 & 64.71 & 95.11 & 69.96 \\
Mean & 55.30 & 169.77 & 130.33 & 187.92 & 102.74 & 85.07 & 113.99 & 91.70 \\
\hline
\end{tabular}

$\mathrm{A}\left({ }^{\circ} \mathrm{C}\right)-\mathrm{J}\left({ }^{\circ} \mathrm{C}\right)$ indicates the cation and silica geothermometers (Table 1$) . \mathrm{A}\left({ }^{\circ} \mathrm{C}\right): \mathrm{Na}-\mathrm{K}, \mathrm{T}=[1217 /(1.483+\log (\mathrm{Na} / \mathrm{K}))]$ - 273.15; B $\left({ }^{\circ} \mathrm{C}\right): \mathrm{Na}-\mathrm{K}, \mathrm{T}=[856 /(0.857+\log (\mathrm{Na} / \mathrm{K}))]-273.15 ; \mathrm{C}\left({ }^{\circ} \mathrm{C}\right): \mathrm{Na}-\mathrm{K}, \mathrm{T}=\{1390 /[\log (\mathrm{Na} / \mathrm{K})+1.75]\}-273.15$; $\mathrm{D}\left({ }^{\circ} \mathrm{C}\right): \mathrm{K}-\mathrm{Mg}, \mathrm{T}=\left\{4410 /\left[14-\log \left(\mathrm{K}^{2} / \mathrm{Mg}\right)\right]\right\}-273.15 ; \mathrm{E}\left({ }^{\circ} \mathrm{C}\right)$ : Chalcedony, $\mathrm{T}=\left[1032 /\left(4.69-\log \mathrm{SiO}_{2}\right)\right]-273.15$; $\mathrm{F}\left({ }^{\circ} \mathrm{C}\right)$ : Quartz, $\mathrm{T}=\left[1309 /\left(5.19-\log \mathrm{SiO}_{2}\right)\right]-273.15 ; \mathrm{J}\left({ }^{\circ} \mathrm{C}\right)$ : Silica, $\mathrm{T}=\left[1000 /\left(4.55-\log \mathrm{SiO}_{2}\right)\right]-273.15$.

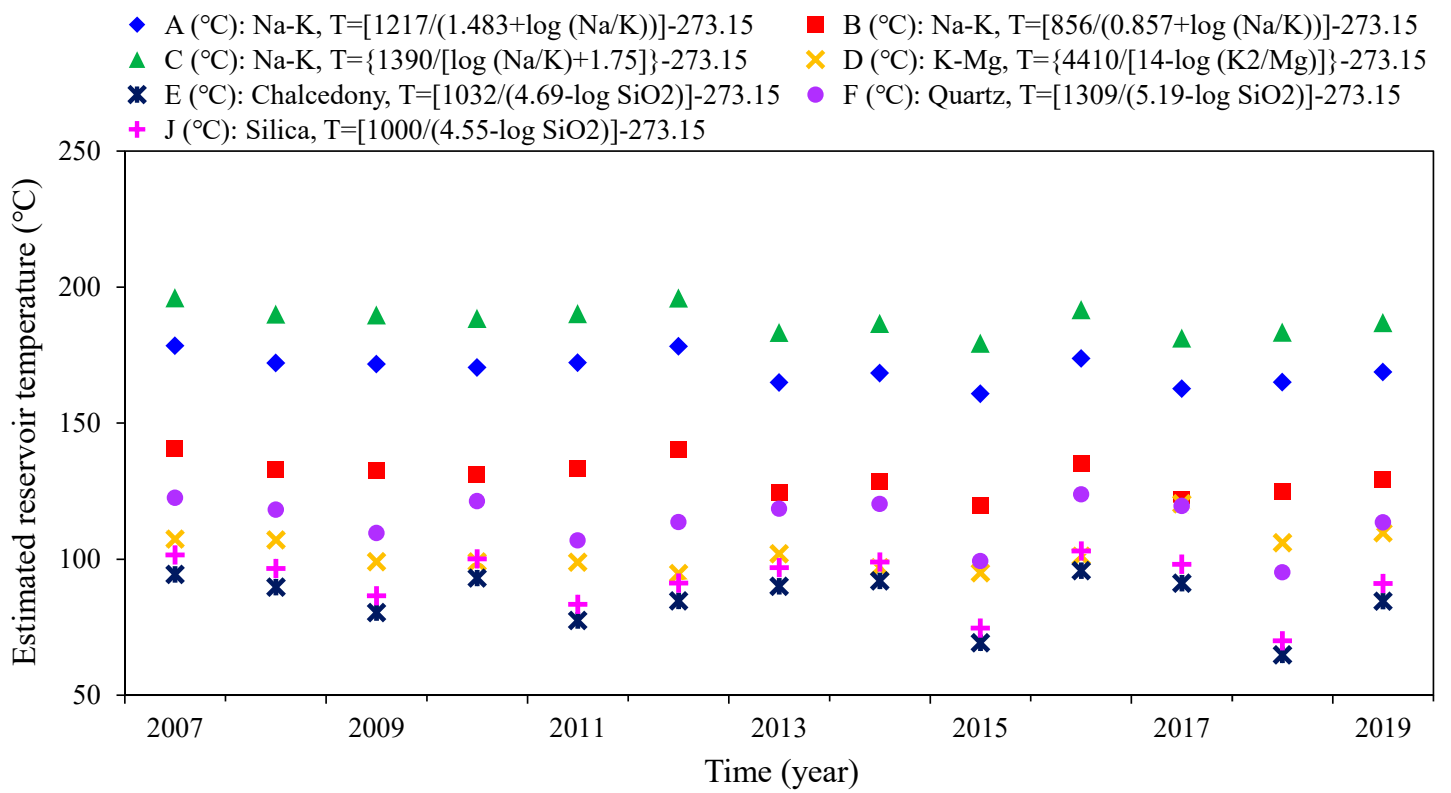

Figure 8. Reservoir temperatures estimated using cation and silica geothermometers. 


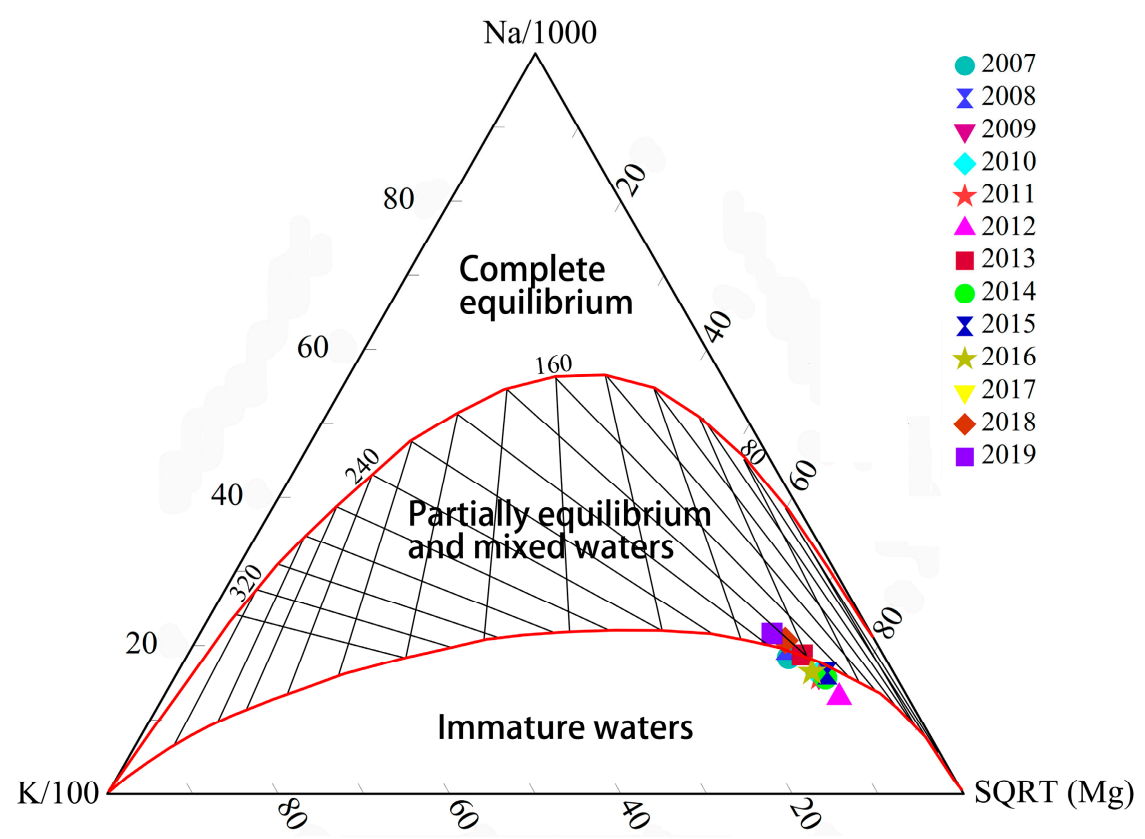

Figure 9. Na-K-Mg Giggenbach Plot with geothermal water samples.

\subsection{Formation Mechanism of Geothermal Water}

In the study area, there are two NNE-trending compressive-torsional faults (Yishui-Tangtou fault and Tangtou-Xujiachanggou fault) and NEE-trending tensional-torsional faults (TangtouZhengiiazhuang fault) (Figure 1). Although the water-resisting degree of each fault is different, the main section belongs to the water-resisting structure. Due to the long-term tectonic activity, the joint and fissure in the affected zone are relatively dense and have certain water conductivity. Surface water and atmospheric precipitation infiltrate deep along joints and fissures, then move southward and southeast along the fault zone from the northern, northeastern and northwestern regions. Groundwater flowing southeast along faults or fissures to the intersection of the fault and Tangtou-Zhengjiazhuang fault in southwest Tangtou is blocked and enriched. The groundwater flowing southward along the Yishui-Tangtou fault in the northeastern part flows to the junction of the Zhengjiazhuang west fault. As the Tangtou-Zhengjiazhuang fault is a Tensional-torsional fault, its water conductivity is stronger than that of Yishui-Tangtou fault. Therefore, groundwater moves southwest along the Tangtou-Zhengjiazhuang fault. Groundwater in Tangtou-Xuyangou fault zone also flows southward along the fault. Groundwater gathers near Tangtou after runoff and heating in deep structure, forming a multi-faceted water convergence point, gradually raising the water head, and discharging in favorable parts [28-30]. Therefore, a conceptual model of Tangtou geothermal system (Figure 10) was constructed based on hydrogeological and geothermal geological conditions.

Geothermal water is mainly formed by deep circulation of groundwater in joints and fissures of two groups of compressive-torsional and Tensional-torsional faults. According to the analysis of lithology, structure, runoff circulation conditions, and groundwater permeability coefficient, the time required for geothermal water to supply from the recharge source to the discharge point is relatively long. In addition, factors such as deep circulation of groundwater and local change of flow direction make the time longer. In the long process of groundwater flow, the chloride ion in geothermal water is the most abundant anion due to the effects of leaching, evaporation, concentration, and human factors. Geothermal water passes through rocks mainly andesite and glutenite [28]. The main mineral components of andesite are feldspar and amphibole, in which the content of sodium and calcium is higher, while the sandy conglomerate is calcareous cementation. Groundwater movement in high temperature and high-pressure environments is conducive to the precipitation of potassium, sodium, 
and calcium ions, while long runoff time is conducive to the accumulation of ions, so that sodium ions in geothermal water gradually increase and form $\mathrm{Na}-\mathrm{Cl}$ type geothermal water with high mineralization.

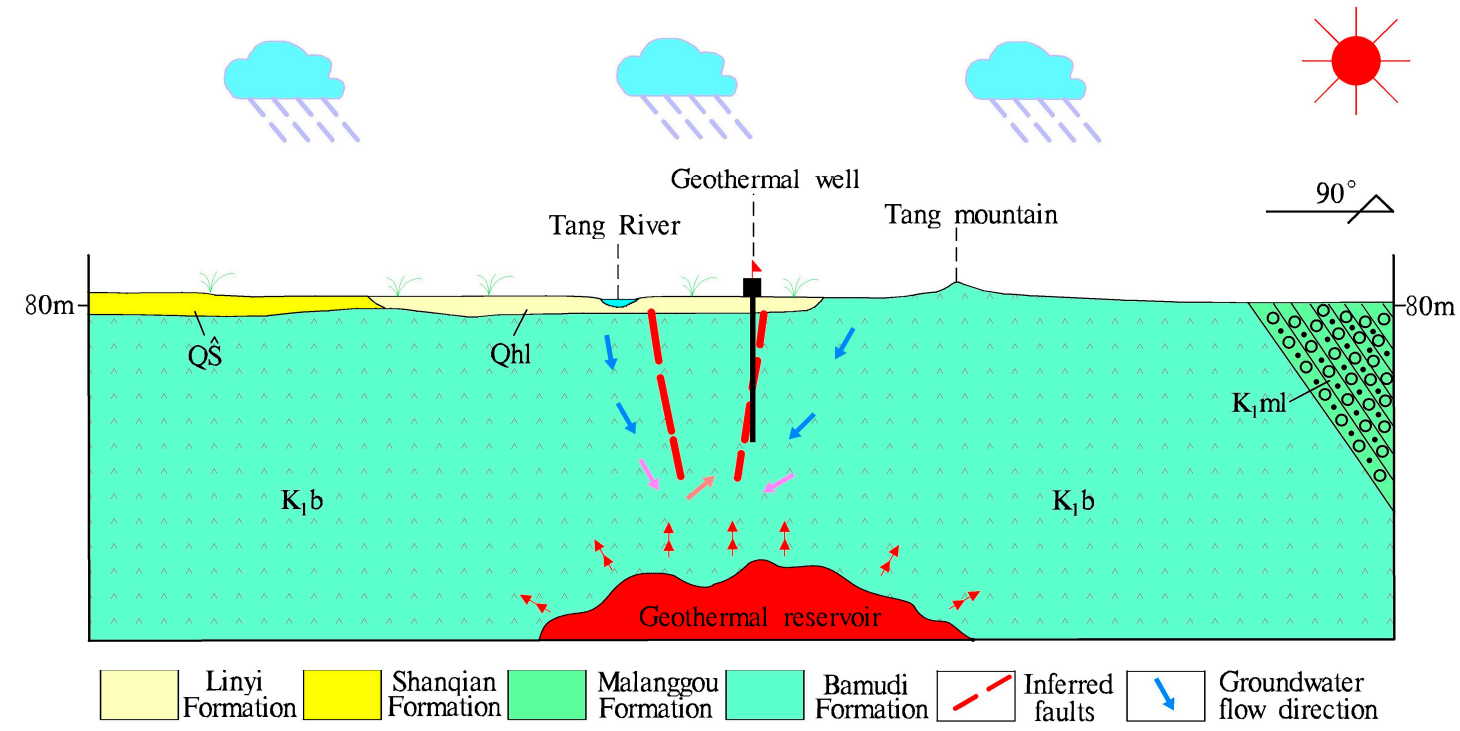

Figure 10. Conceptual model for the Tangtou geothermal waters.

\subsection{Temporal Variations of Geothermal Water Quality}

The variation of hot water exploitation in geothermal wells over the years is shown in Figure 11. It can be seen that the exploitation of geothermal water from 2005 to 2009 is maintained at $500 \mathrm{~m}^{3} / \mathrm{d}$, from 2010 to 2012 at $700 \mathrm{~m}^{3} / \mathrm{d}$ to $800 \mathrm{~m}^{3} / \mathrm{d}$, and from 2013 to 2019 at an average of $500 \mathrm{~m}^{3} / \mathrm{d}$. In 2019, the dynamic water level of geothermal well decreased $53.29 \mathrm{~m}$ compared with 2007, with an average annual decrease of $4.44 \mathrm{~m}$, while the static water level decreased $3.15 \mathrm{~m}$ compared with 2007, with an average annual decrease of $0.26 \mathrm{~m}$. Precipitation in the study area showed significant volatility in 2007-2019, with relatively high precipitation in 2007 and 2008. In addition, the physical and chemical components of geothermal water show significant changes.

As can be seen from Figure 11, the content of the main chemical components in geothermal water varies obviously and shows certain fluctuation. On the whole, TDS, $\mathrm{TH}, \mathrm{Na}^{+}, \mathrm{Ca}^{2+}, \mathrm{Cl}^{-}$, and $\mathrm{K}^{+}$ showed a certain stage. The components decreased gradually from 2007 to 2012, while increased gradually with time after 2013. This is consistent with the changing trend of geothermal water exploitation and precipitation. With the increase of exploitation of geothermal water and precipitation, the recharge of surface water and shallow cold water to geothermal water increases, and the ions content in geothermal water decreases. After the decrease of exploitation and precipitation, the ions content increases gradually.

On the whole, $\mathrm{SO}_{4}{ }^{2-}$ changes slightly and the content of $\mathrm{SO}_{4}{ }^{2-}$ basically remains stable, and $\mathrm{HCO}_{3}{ }^{-}$ shows a gradual downward trend, but both $\mathrm{SO}_{4}{ }^{2-}$ and $\mathrm{HCO}_{3}{ }^{-}$fluctuated greatly. $\mathrm{NO}_{3}{ }^{-}$can reflect the impacts of human input on the water environment. The fluctuation of $\mathrm{NO}_{3}{ }^{-}$in geothermal water is large, which also shows that geothermal water is recharged by surface water infiltration and lateral recharge of cold groundwater. $\mathrm{pH}$ showed a tendency to rise first, then decline, and then stabilize, but the overall change was small. In addition, the fluctuation of ion content in geothermal water may be related to the sampling time of geothermal water. In 2007, 2009-2012, 2015-2018, the sampling time is June or September of each year. However, the sampling time of 2013 was November, 2014 was March, and 2019 was January. Influenced by atmospheric precipitation, the water level of Tang River rise, the recharge of surface water and shallow cold groundwater to geothermal wells increased, resulting in the relative fluctuation of ion content. Also, it may be related to the exploitation of geothermal water in other geothermal wells in the study area. 

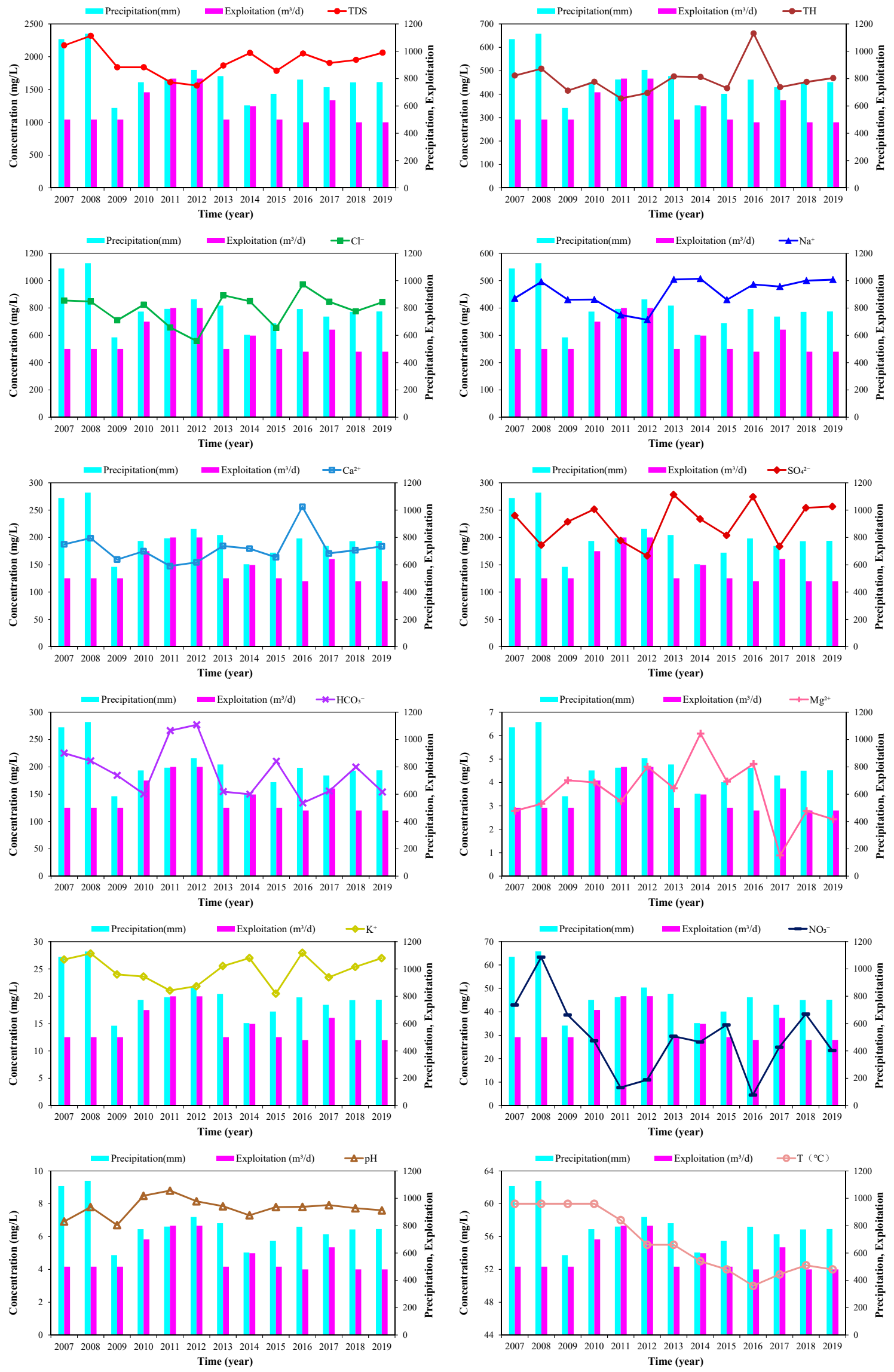

Figure 11. Variation trend of major components and exploitation and precipitation. 
The temperature of geothermal water changes with time in three stages: (1) before 2010, the temperature of geothermal water is basically unchanged, (2) from 2010 to 2016, the temperature of geothermal water decreases year by year, (3) from 2016 to 2019, the temperature of geothermal water shows a gradual upward trend. The geothermal water temperatures of 2007,2013 and 2019 were $60^{\circ} \mathrm{C}$, $55^{\circ} \mathrm{C}$, and $52{ }^{\circ} \mathrm{C}$, respectively. Compared with 2007, the temperature of geothermal water in 2019 decreased by $8{ }^{\circ} \mathrm{C}$, with an average annual decrease of $0.66^{\circ} \mathrm{C}$. Compared with 2013 , it decreased by $3{ }^{\circ} \mathrm{C}$, with an average annual decrease of $0.6^{\circ} \mathrm{C}$. As can be seen from Figure 11, the precipitation is approximately proportional to the exploitation. With the increase of the exploitation and precipitation, the temperature of geothermal water decreases obviously, but when the exploitation is less than the precipitation, the water temperature still decreases, which indicates that there are other geothermal wells are exploiting thermal water in the study area.

In order to better understand the influence of geothermal water exploitation and precipitation on the main physicochemical parameters of geothermal water, the monitoring data from 2007 to 2019 were used for grey correlation analysis. Using the Formulas (1)-(7), the geothermal water exploitation and precipitation are taken as the primary sequence and the main physicochemical parameters as the sub-sequence to calculate the correlation degree. From Table 5, it can be seen that the correlation degree between geothermal water extraction and precipitation and the main physicochemical parameters is greater than 0.6 , which indicates that the extraction and precipitation have a significant impact on the main physicochemical parameters. Among them, the correlation degree of $\mathrm{Mg}^{2+}, \mathrm{HCO}_{3}{ }^{-}, \mathrm{SO}_{4}{ }^{2-}$, $\mathrm{NO}_{3}{ }^{-}$, and $\mathrm{pH}$ with geothermal water exploitation is higher, which is $0.81,0.75,0.70,0.71$, and 0.71 , respectively. The correlation degree of $\mathrm{NO}_{3}{ }^{-}$and $\mathrm{Mg}^{2+}$ with precipitation is higher, which is 0.72 and 0.70 , respectively. In addition, the correlation degree between $\mathrm{NO}_{3}{ }^{-}$and exploitation and precipitation are greater than 0.7 , which again indicates that geothermal water is recharged by surface water and shallow cold groundwater.

Table 5. $\rho(\mathrm{k})$ and correlation degree between exploitation, precipitation and major physicochemical.

\begin{tabular}{cccc}
\hline Parameter & $\boldsymbol{\rho}(\mathbf{k})$ & Exploitation & Precipitation \\
\hline $\mathrm{Cl}^{-}$ & 0.29 & 0.69 & 0.65 \\
$\mathrm{SO}_{4}{ }^{2-}$ & 0.36 & 0.70 & 0.64 \\
$\mathrm{HCO}_{3}{ }^{-}$ & 0.34 & 0.75 & 0.63 \\
$\mathrm{NO}_{3}{ }^{-}$ & 0.80 & 0.71 & 0.72 \\
$\mathrm{~K}^{+}$ & 0.23 & 0.62 & 0.67 \\
$\mathrm{Na}^{+}$ & 0.29 & 0.67 & 0.64 \\
$\mathrm{Ca}^{2+}$ & 0.24 & 0.64 & 0.68 \\
$\mathrm{Mg}^{2+}$ & 0.77 & 0.81 & 0.7 \\
$\mathrm{TH}$ & 0.24 & 0.65 & 0.69 \\
$\mathrm{pH}$ & 0.22 & 0.71 & 0.69 \\
$\mathrm{TDS}$ & 0.22 & 0.62 & 0.66 \\
$\mathrm{~T}\left({ }^{\circ} \mathrm{C}\right)$ & 0.2 & 0.64 & 0.69 \\
\hline
\end{tabular}

Previous studies have shown that over-exploitation of geothermal water since the 1980s has caused environmental geological problems such as a decrease in water temperature and a decrease in the content of water chemical components $[25,28,29]$. This study also indicates that the water temperature and the content of hydrochemical components of Tangtou geothermal water are significantly correlated with the exploitation of geothermal water and the precipitation. With the increase of exploitation of geothermal water, surface water, and shallow underground cold water increase the recharge of geothermal water and then affect the physical and chemical components of geothermal water. Therefore, in order to better develop and utilize geothermal water resources, the exploitation of geothermal water should be controlled. The water level and quality of the surrounding wells and Tang River should be monitored during the mining process, and the exploitation should be adjusted appropriately according to the monitoring data. In addition, the geothermal tail water should be treated and 
discharged after reaching the standard, so as not to pollute the nearby groundwater and agricultural ecological environment.

\section{Conclusions}

Based on the comprehensive analysis of geological and geothermal geological conditions, the hydrochemical characteristics, origins and temporal variations of geothermal water quality were discussed by using the hydrochemical data of Tangtou geothermal water from 2007 to 2019, and a conceptual model of geothermal system was established. The main conclusions are as follows:

(1) From 2007 to 2019 , the temperatures of geothermal water range from $50{ }^{\circ} \mathrm{C}$ to $60{ }^{\circ} \mathrm{C}$ with a mean of $55.93{ }^{\circ} \mathrm{C}$. Contents of major ions in the geothermal water are $\mathrm{Na}^{+}>\mathrm{Ca}^{2+}>\mathrm{K}^{+}>\mathrm{Mg}^{2+}$ and $\mathrm{Cl}^{-}>\mathrm{SO}_{4}{ }^{2-}>\mathrm{HCO}_{3}{ }^{-}>\mathrm{NO}_{3}{ }^{-}$, which makes the geothermal water belong to $\mathrm{Cl}-\mathrm{Na}$ type. The measured TDS values of geothermal waters were $1560-2512 \mathrm{mg} / \mathrm{L}$ and $\mathrm{pH}$ were in the range of 6.7-8.8.

(2) A positive correlation was found between $\mathrm{Cl}^{-}$and $\mathrm{Na}^{+}, \mathrm{K}^{+}, \mathrm{Ca}^{2+}$, and $\mathrm{SiO}_{2}$, while $\mathrm{Cl}^{-}$and $\mathrm{HCO}_{3}{ }^{-}$had a significant negative correlation. Water-rock interaction in the process of runoff is the main factor controlling the chemical composition of geothermal water, as well as mixing processes. Calculated SI values indicated that the geothermal water was saturated with respect to quartz, chalcedony, dolomite, calcite, and aragonite, while unsaturated with respect to anhydrite, halite, and gypsum.

(3) Geothermal water passes through a long runoff path and a slower deep water cycle and rises through the tectonic fracture zone. The geothermal water was recharged by shallow underground cold water. At the intersection of Tangtou-Zhengjiazhuang fault and Tangtou-Xujiachanggou fault, the terrain is low-lying, the fissures are developed, and the geothermal water is blocked by the faults, which enriches in the deep underground near Tangtou.

(4) Based on cation and silica chemical geothermometers, water temperatures estimated by the cation geothermometers ranged from 94.63 to $196.10^{\circ} \mathrm{C}$, while temperatures estimated the silica geothermometers from indicated a result of ranging from 69.13 to $123.75^{\circ} \mathrm{C}$. Na-K-Mg $1 / 2$ ternary diagram suggested that thermal water samples from 2007 to 2019 contain immature waters and partially equilibrated or mixed waters.

(5) Based on the grey relational analysis, the main physicochemical components of geothermal water are obviously correlated with the precipitation and the exploitation of geothermal water, and all the correlation coefficients are greater than 0.6. Overall, TDS, $\mathrm{TH}, \mathrm{Na}^{+}, \mathrm{Ca}^{2+}, \mathrm{Cl}^{-}$, and $\mathrm{K}^{+}$showed a trend of decreasing first and then increasing, while $\mathrm{Mg}^{2+}$ displayed a reverse trend with these components. The temperature of geothermal water changes with time in three stages: steady, decline, and increase. In addition, geothermal water temperature also was influenced by other geothermal wells exploiting hot water in the study area.

Author Contributions: Conceptualization, Z.G., J.F. and J.L.; Methodology, Z.G., J.L. and J.F.; Formal Analysis, Z.G., J.L., F.L., M.W., J.F. and G.W.; Writing-Original Draft Preparation, Z.G., J.L., J.F. and M.W.; Writing-Review \& Editing, Z.G., J.L. and J.F.; Resources, F.L. and G.W.; Project Administration, Z.G., F.L. and G.W.; All authors read and approved the final manuscript.

Funding: This research received no external funding.

Acknowledgments: This research was supported by the Seventh Institute of Geology and Mineral Exploration of Shandong Province and the Shandong Geological Environmental Monitoring Station. The authors sincerely thank the researchers and staff members for their help and thank editors and reviewers for reviewing the manuscript.

Conflicts of Interest: The authors declare no conflict of interest. 


\section{References}

1. Yan, B.; Qiu, S.W.; Liu, Z.; Xiao, C. Characteristics of the geothermal water in Changbai Mountain volcanic region, northeast of China. Arab. J. Geosci. 2017, 10, 261. [CrossRef]

2. Han, D.; Liang, X.; Jin, M.; Currell, M.; Song, X.; Liu, C. Evaluation of groundwater hydrochemical characteristics and mixing behavior in the Daying and Qicun geothermal systems, Xinzhou Basin. J. Volcanol. Geoth. Res. 2010, 189, 92-104. [CrossRef]

3. Wang, X.; Lu, G.; Hu, B.X. Hydrogeochemical Characteristics and Geothermometry Applications of Thermal Waters in Coastal Xinzhou and Shenzao Geothermal Fields, Guangdong, China. Geofluids 2018, 2018, 1-24. [CrossRef]

4. Yalcin, T. Geochemical characterization of the Biga Peninsula thermal waters (NW Turkey). Aquat. Geochem. 2007, 13, 75-93. [CrossRef]

5. Tan, H.; Zhang, W.; Chen, J.; Jiang, S.; Kong, N. Isotope and geochemical study for geothermal assessment of the Xining basin of the northeastern Tibetan Plateau. Geothermics 2012, 42, 47-55. [CrossRef]

6. Wang, S.; Liu, Z.; Shao, J. Hydrochemistry and H-O-C-S Isotopic Geochemistry Characteristics of Geothermal Water in Nyemo-Nagqu, Tibet. Acta Geol. Sin-Engl. 2017, 91, 644-657. [CrossRef]

7. Chenaker, H.; Houha, B.; Vincent, V. Hydrogeochemistry and geothermometry of thermal water from north-eastern Algeria. Geothermics 2018, 75, 137-145. [CrossRef]

8. Deepa, S.; Venkateswaran, S. Appraisal of groundwater quality in upper Manimuktha sub basin, Vellar river, Tamil Nadu, India by using Water Quality Index (WQI) and multivariate statistical techniques. Model. Earth Syst. Environ. 2018, 4, 1165-1180. [CrossRef]

9. Liu, J.; Hao, Y.; Gao, Z.; Wang, M.; Liu, M.; Wang, Z.; Wang, S. Determining the factors controlling the chemical composition of groundwater using multivariate statistics and geochemical methods in the Xiqu coal mine, North China. Environ. Earth Sci. 2019, 78, 364. [CrossRef]

10. Ma, F.; Wei, A.; Deng, Q.; Zhao, H. Hydrochemical characteristics and the suitability of groundwater in the coastal region of Tangshan, China. J. Earth Sci. 2014, 25, 1067-1075. [CrossRef]

11. Dong, Y.; Duan, Z. A new determination method for identification coefficient of grey relational grade. J. Xi'an Univ. Archit. Technol. (Nat. Sci.) 2008, 4, 589-592.

12. Li, J.; Li, X.; Lv, N.; Yang, Y.; Xi, B.; Li, M.; Bai, S.; Liu, D. Quantitative assessment of groundwater pollution intensity on typical contaminated sites in China using grey relational analysis and numerical simulation. Environ. Earth Sci. 2015, 74, 3955-3968. [CrossRef]

13. Lv, F. Research on the identification coefficient of relational grade for grey system. Syst. Eng. Theor. Pract. 1997, 6, 50-55.

14. Fan, K.; Wu, H. A new method on identification coefficient of relational grade for gray system. J. Wuhan Univ. Technol. 2002, 24, 86-88.

15. Belhai, M.; Fujimitsu, Y.; Bouchareb-Haouchine, F.Z.; Haouchine, A.; Nishijima, J. A hydrochemical study of the Hammam Righa geothermal waters in north-central Algeria. Acta Geochim. 2016, 35, 271-287. [CrossRef]

16. Başaran, C.; Gökgöz, A. Hydrochemical and isotopic properties of Heybeli geothermal area (Afyon, Turkey). Arab. J. Geosci. 2016, 9, 586. [CrossRef]

17. Fournier, R.O. Chemical geothermometers and mixing models for geothermal systems. Geothermics 1977, 5, 41-50. [CrossRef]

18. Truesdell, A.H. Summary of section III. Geochemical techniques in exploration. In Proceedings of the 2nd UN Symposium on the Development and Use of Geothermal Resources, San Francisco, CA, USA, 20-29 May 1976; Volume 1, pp. liii-lxxix.

19. Giggenbach, W.F. Isotopic composition of geothermal water and steam discharges. In Application of Geochemistry in Geothermal Reservoir Development; D'Amore, F., Ed.; UNITAR/UNDP: Vial del Corso, Italy, 1992; pp. 253-273.

20. Piper, A.M. A graphic procedure in the geochemical interpretation of water-analyses. Neurochem. Int. 1944, 25, 27-39. [CrossRef]

21. Giggenbach, W.F. Geothermal solute equilibria. Derivation of Na-K-Mg-Ca geoindicators. Geochim. Et Cosmochim. Acta. 1988, 52, 2749-2765. [CrossRef]

22. Gueroui, Y.; Maoui, A.; Touati, H.; Guettaf, M.; Bousbia, A. Hydrogeochemical and environmental isotopes study of the northeastern Algerian thermal waters. Environ. Earth Sci. 2018, 77, 747. [CrossRef] 
23. Vengosh, A.; Helvac1, C.; Karamanderesi, I.S.H. Geochemical constraints for the origin of thermal waters from western Turkey. Appl. Geochem. 2002, 17, 163-183. [CrossRef]

24. Liu, J.; Gao, Z.; Wang, M.; Li, Y.; Ma, Y.; Shi, M.; Zhang, H. Study on the dynamic characteristics of groundwater in the valley plain of Lhasa City. Environ. Earth Sci. 2018, 77, 646. [CrossRef]

25. Wang, H.; Wang, S.; Liu, L.; Cao, Y.; Shi, M.; Li, T.; Sun, W. Hydrochemical and environmental isotopic characteristics of geothermal resources in the Linyi segment of the Yishu fault zone. Shanghai Land Res. 2018, 39, 90-94.

26. Belhai, M.; Fujimitsu, Y.; Nishijima, J.; Bersi, M. Hydrochemistry and gas geochemistry of the northeastern Algerian geothermal waters. Arab. J. Geosci. 2017, 10, 8. [CrossRef]

27. Foued, B.; Hénia, D.; Lazhar, B.; Nabil, M.; Nabil, C. Hydrogeochemistry and geothermometry of thermal springs from the Guelma region, Algeria. J. Geol. Soc. India 2017, 90, 226-232. [CrossRef]

28. Wang, T.G.; Feng, Z.M.; Chang, Y.X.; Song, C.B.; Wei, Z.R.; Liu, S.J. Environmental Geological Problems Caused by Hot Spring Development in Tangtou and the Prevention Countermeasure. Chin. J. Geol. Hazard Control 2002, 1, 85-90.

29. Dong, Y.M.; Li, Z.H.; Chen, S.L.; Zhao, G.L. Geothermal resource exploitation, utilization and protection in Linyi segment of Yishu fault. Res. Dev. Mark. 2009, 25, 1031-1033.

30. Yang, Q.J.; Yang, M.; Li, M. Study on the Geotherm-forming Geological Condition in the Yishu River Fault Zone. Geol. Surv. Res. 2008, 31, 278-284.

(C) 2019 by the authors. Licensee MDPI, Basel, Switzerland. This article is an open access article distributed under the terms and conditions of the Creative Commons Attribution (CC BY) license (http://creativecommons.org/licenses/by/4.0/). 